\title{
TANULÓTÖRTÉNETEK AVAGY EGY PEDAGÓGIA SZÜLETÉSE
}

\section{GOLNHOFER ERZSÉBET}

\author{
az Eötvös Loránd Tudományegyetem Neveléstudományi Intézetének \\ ny. habil egyetemi docense \\ golnhofer.erzsebet@ppk.elte.hu
}

\begin{abstract}
„Dráma a párbeszédekben.” „Ellenállás a nyelvben: lehetöség a kritikai szubkultúrára.” „Az önmagát háttérbe szoritó tanitás.” „Öntudatra ébredés.” „A történelem pulzusáról.” "Iskolabezárás." A könyvnek ez a hat témája több dolgot is kifejez: jelzi a könyv stílusát, a szinte drámaszerủen kibomló szöveget, és felvillant egy sajátos nevelési szemléletmódot. Az írással mélyebben ismerkedve láthatóvá válik, hogy a szerző - az írásos müfaj keretei között - izgalmas párbeszédre hív, amikor a nyolcvanas évek végén kezdődő tanítási tapasztalatait osztja meg olvasóival.

A Brooklynban, Bronxban és New Yorkban társadalomtudományokat tanító Winthrop R.. Holder a prológusban úgy fogalmaz, hogy a könyv valójában nem a nevelésről szól, hanem egy biográfia, mégpedig a diákoké, a szerzőé és egy ideáé (Winthrop, 2007, XI.). Az olvasó haladva a könyvben azt érzékelheti, hogy az idea szorosan kapcsolódik egy olyan neveléshez, amelynek középpontjában az autonóm, kreatív, kíváncsi, cselekvö diák áll, akivel a „tanár” együtt dolgozik a diákban lévő lehetőségek kiaknázásáért. A könyv tehát egy sajátos nevelésröl, pontosabban annak születéséről, formálódásáról szól, bár valóban életrajznak is tekinthető, hiszen mindegyik fejezet, vagy inkább drámai felvonás alapvetően egy-egy diáktörténetre és a szerző reflexióira épül. A szövegek sokféle dokumentum alapján jöttek létre: a szerző saját munkájáról készített jegyzeteiből, diákok írásaiból, leveleiből, szülőkkel és tanártársakkal folytatott beszélgetések részleteiből. A munkában összekapcsolódnak az elbeszélések, a leírások és a reflexiók, s az egymásba fonódó történetek, reflexiók az olvasókat is kritikus reflexiók megfogalmazására ösztönzik. A történetek és reflexiók dinamikus folyamatából építkező szöveg magával ragadja az olvasót, a történetek átélésén keresztül szinte személyes viszony alakulhat ki a „szereplökkel”.

Az elmúlt két-három évtizedben számos tudományágban, így többek között a szociológiában, pszichológiában, neveléstudományban erőteljesen érvényesült az a szemléletmód, hogy újra értelmezzék a némaságra itélt, dehumanizált emberek helyzetét. A kritikai pedagógia művelöi a nevelés, az iskoláztatás olyan diskurzusát indították el, amely az oktatás, illetve az oktatásra ható hatalmi viszonyokkal foglalkozott. Kitüntetett szempontként, elvként jelent meg, hogy hangot kapjanak az oktatásban csendre ítélt diákok, hogy párbeszéd, együttmüködés alakuljon ki az ok-
\end{abstract}


tatásban marginalizált diákokkal. Erre teremtett lehetőségeket a könyv szerzője az osztályteremben, az iskolában: szakított a bürokratikus, monotóm neveléssel, a tudást elosztó hatalmi/tanári szemlélettel, a dekontextualizált tanulási környezettel. A világ megismerését, a tudásszerzést együttes kutatásként értelmezte, amelyben tanár és tanuló partnerként lép dialógusba egymással. A szerző a diákok történeteihez kötött dialóguson keresztül nem csak azt érzékelteti, hogy miképpen érvényesítik hangjukat a diákok, de azt a mentalitást is kifejezésre juttatja, hogy a diákok szava érvényes, legitim, és nem csak a hagyományos tanár-diák hatalmi viszonyba való betagozódást szolgálja.

Holder, mint az elmúlt egy-két évtizedben oly sok tanár, kezdö tanárként szembesült a diákok ellenállásával, motiválatlanságával, az iskolai kudarcokkal, az iskolából kilépők elégtelen tudásával, a felnőttek, a tanárok és a diákok közötti párbeszéd-képtelenséggel. Érzékeny emberként figyelt a diákokra az osztályteremben, különféle szociális tereikben, például a folyosón, az ebédlőben és az iskolán kívüli találkozásaikon. Eközben érzékelte a diákok által gyakran csak rejtetten megfogalmazott igényt, véleményt: „Miért nincsenek kihívások a számunkra?” (22. o.) A holisztikus szemléletü, könyvterjedelmű válaszból a recenzió keretei között néhány egymással szorosan összefüggő elemre szeretném ráirányítani a figyelmet: a tanulásnak, a tudásnak, a tanítási felfogásnak és a vitának, a kritikai gondolkodásnak az értelmezésére, valamint a gyakorlati megvalósulás néhány jellegzetességére.

A passzív, a csendre ítélt ifjakat váratlanul érte Holder tanítási módja: „Belépve egy osztályba, ahol nem a megszokott rutinnal találkoztam, a jegyzetek másolása helyett a 'csináld most' érvényesült, sokkot kaptam, meglepetés erejével hatott rám. Nem szoktam a vitákhoz, sohasem élveztem a 'részvételt' az osztályban. De hozzászoktam, hogy olyan osztályban vagyok, ahol respektálják a tanuló hangját. Calypso osztály, így nevezzük a 10. évfolyamos osztályunkat. Azért használom ezt a kifejezést, mert a calypso olyan zene, ahol különbözö eszközöket használnak, hogy egy dallamot hozzanak létre. Bár az eszközök nem mindig vannak összhangban, gyakran harcolnak egymással az uralomért, de az egyveleg mindig gondoskodik egy végső gyönyörü eredményről, a harmonikus zenéről.” (31. o.) A világ megismerésére, a tanulásra azzal a szemlélettel és gyakorlattal tudta ösztönözni Holder diákjait, hogy a tanítást nem egyszerüen a tudás átadásaként értelmezte, hanem olyan lehetőségek biztosításaként, amelyben a diákok saját maguk konstruálhatják meg saját, személyes tudásukat. Nézzük meg, hogy melyek voltak ezek a lehetőségek, illetve feltételek!

Szeretném elkerülni a felületes módszertani, technikai megközelítését, ugyanakkor úgy látom, hogy elsőként érdemes a vita, a kritikai gondolkodás szerepével foglalkozni. Maga a szerző is hangsúlyozza ennek jelentőségét, s a viták a tanulók történeteiben is tanulást meghatározó elemként jelentek meg.

Mi késztette a szerzöt arra, hogy ösztönözze a vitákat, hogy respektálja a diákok véleményét? Holder nem egy vagy több neveléselméletből származtatta ezt a törek- 
vését, gyakorlatát, hanem különböző gyermekkori, családi és tanári informális tapasztalatából, de fóképpen a tanulóktól és szüleiktől származó kihívásokból. A vita, a kritikai gondolkodás helyét kereső szerző érvei között fontos szerepet kapott, hogy elméleti megfontolások helyett komolyan kell venni a városi ifjúság problémáit (kimaradások, lemorzsolódások, érdektelenség stb.).

A kritikai gondolkodás fejlesztését nem a kritikai gondolkodás guruinak véleménye, gyakorlata szerint értelmezte s valósította meg Holder, inkább Freire szemléletét érvényesítette, aki kiemelte többek között, hogy figyeljünk mindenre, ami „szembejön” velünk (megfelelő intellektuális szinten), és ennek során emberi kötelességünk, hogy a demokráciával azonosuljunk és ne az elitizmussal (Freire, 1998, id. Holder, 16. o.). A kritikai gondolkodásnál a lényeg nem a terminus technicusok használata, vagy a formális lépések, módszerek követése, hanem inkább az, hogy a tanulók felfedezhessék, gyakorolhassák a kritikai gondolkodást. Kiindulópontja az volt, hogy a tanulók számára személyes jelentéssel biró problémák, témák teszik érdekessé a vitát, fontossá a kritikus hozzáállást, és támogatják a diákokat abban, hogy elkötelezettek és készek legyenek a mindennapokban a dialektikus s kritikai gondolkodásra.

Holder sokféle módon ösztönözte a különböző nyelvi, kulturális hátterü diákok között, az osztályteremben, a nyílt vitákat. A történetek elmesélése fontos eszköz volt a diákok számára a jelentésadásban, a tudás konstruálásában mind szóbeli, mind írásos formájában. Emellett, ehhez kapcsolódóan a tanítás szerves része volt a kritikai gondolkodás bátorítása. Olyan tanulási légkört alakított ki, amely arra késztette diákjait, hogy kritikusan reagáljanak saját és mások (így társaik és tanáruk) gondolataira, vegyék komolyan saját és mások nézeteit. Erős motiváló szerepet játszott, hogy értelmezhették, birálhatták a tanitási gyakorlatot, hogy beépítették a mindennapok problémáit a tanításba, hogy kinyomtatták a diákok írásait, s független diákújságokat müködtettek (Crossing Swords, 1988-2000; CounterCurrents, 2002-2004). Az irás saját élményü kipróbálása ösztönözte a diákokat a saját hang megtalálására, aktívabb megfigyelővé tette öket, érdeklödőbbé társaik élményei iránt, támogatta őket abban, hogy íróként is olvassanak, kutatóként is kipróbálják önmagukat. Lehetőség nyílt a független gondolkodók, írók és olvasók közösségének a kialakulására is. Az órákon a diákok és a szerző (tanár) ugyanazon dokumentumokat olvasta, ugyanazokon a dokumentumokon dolgozott, vitatkozott, s ez életre keltette, érdekessé, mozgalmassá tette az órákat.

Az írások, a narratívák „hasznát” a diákok is árnyaltan látták: „Az írás segített nekem, hogy kifejezhessem a gondolataimat és az érzéseimet... Az írás fizikailag és mentálisan is segített... Az írás olyan volt mint egy terápia, mert képessé tett engem arra, hogy kifejezzem magamat, és elkergette azokat a negatív gondolatokat, hogy nem tudom építeni magamat belülröl...” (89. o.). „Azért írtam, mert örömöt okozott... Gyakran azért írtam, hogy távol tartsam a gondokat... Azért írtam le valamit 
mielött hozzá kezdtem volna, hogy lássam, vajon megéri-e. Mindent egybe véve akkor írtam a szabad időben, amikor unatkoztam.” (90. o.).

A diákok mindennapjaihoz erősen kötődő témák megvitatása, az önreflexió, a tanításra vonatkozó kritikus reflexió előhívása során nem hallgatóságra, hanem közönségre talált tanár és tanuló egyaránt. Szembesülhet az olvasó azzal is, hogy mindez csak akkor valósul meg, ha a tanár nem csak figyelö partner, de olyan együttmüködő, aki elfogadja és érvényesíti a hatalom multidimenzionális voltát. Holder nem elméletileg elemzi az oktatás hatalmi viszonyait, hanem diákjai történetein és az azokhoz kapcsolódó reflexiókon keresztül ad lehetőséget egy demokratikus pedagógiát, cselekvést megalapozó diskurzusra. A szerző azt tapasztalta, hogy a nyílt viták megerősítették a tanulók abban, hogy tanuljanak, ti. ,az osztály mint intellektuális csatamező tolta, nyomta a diákokat az öntanitás irányába és a demokratikusabb osztály felé, amelyben a tanulók kollektív hangja van elötérben.” (5-6. o.). A viták során a diákok megtanulták úgy látni, érezni magukat, mint akik a nevelés alanyai, kevésbé a tárgyai, s ezzel összefüggésben ösztönzést kaptak saját perspektíváik kifejezésére, fejlesztésére.

A fentiek alapján is látható talán, hogy a kritikai gondolkodás nem csak módszert jelentett Holder tanításában, hanem egy sajátos mentalitást: hangot adni a hangnélkülieknek, kitüntetett figyelmet a különbségeknek, az eltérő „,beszédmódoknak,” reagálni a tudás, a hatalom és a kontroll összefüggéseire.

A diákírások nem csak az önkifejezés eszközei voltak, nem csak megörökítettek gondolatokat, érzéseket, de szinte alternatív tantervként is müködtek. S ezzel eljutottunk a „calypso osztály” újabb fontos sajátosságához, a tudás értelmezéséhez, gyakorlati megjelenéséhez.

A pedagógia világában változatos tudásértelmezések léteznek, hatnak. Az elmúlt két-három évtizedben különböző kognitív, konstruktivista megközelítések és/vagy posztmodern elemzések hangsúlyozták a tudáskonstruálás egyedi és/vagy szociális jellegét. Sorra születtek olyan munkák, amelyekben különböző szemlélettel és sokféle szempont mentén foglalkoztak a gyermek- és/vagy ifjúsági kultúrák sokféleségével és sajátosságaival. Különböző pozitivista és/vagy értelmező jellegü kutatások eredményeként nagyszámú gyermektudományt leíró produktum készült. Számos nemzetközi és országos iskolai eredményességvizsgálat, sokféle elégedettségvizsgálat és az oktatásban érdekeltek mindennapi tapasztalatai arra utalnak, hogy a gyermek/ifjúsági kultúrák leírásai nem hatottak eléggé a pedagógiai gyakorlatra. Bár Holder munkájában is megjelennek a konstruktivizmushoz kapcsolható gondolati elemek, de inkább a kritikai pedagógia szellemiségének hatását lehet érzékelni, különösen a következők kapcsán:

a) A tudás szociális konstrukció.

b) Az oktatásban szelíd elnyomás érvényesül a tudást birtoklók (tanárok) részéről a diákokkal szemben; a tudás privilegizálása a tanárt hozza előnyös helyzetbe. 
c) Nem lenne szabad elkendőzni, az oktatásból kirekeszteni a nemhez, az osztályhoz, a kultúrához kötődő tudás-együtteseket, amelyeket a diákok (például serdülők) valamelyik csoporthoz tartozóan hoznak létre.

Holder mindennapi tapasztalatai felerösítették azt a nézetét, hogy napjainkban az iskolai megismerési válságnak központi problémái a következők: egyrészt nem tudjuk mit és mennyit tudnak a diákok, másrészt arról is keveset tudunk, miképpen tanulnak. Nap mint nap szembesült azzal, hogy nincs kapcsolat a tanítás és a tanulók informális tanulása között, hogy a diákok erősségeit nem lehet a tantárgyteszteken keresztül megismerni. Sokkolta őt a diákok apátiája, motiválatlansága, ezért arra törekedett, hogy hidat építsen a különböző hátterü családi és iskolai diskurzusok közé, hogy az oktatásban felhasználja a diákoknak azokat a tapasztalatait, amelyeket a populáris kultúrában szereztek, ezáltal kapcsolatot tudjon teremteni a diákok informális tanulása és a tanterv között. Többféle eljárást talált arra, hogy beépítse a populáris kultúrát a társadalomtudományok „tanításába.” Felhasználta a különböző ellenállást kifejező zenéket (calypso, reggae, rap stb.), olyan irodalmi műfajokat alkalmazott, amelyek kapcsolatban voltak a „lázadó” zenékkel (szatíra, paródia stb.). Fontos szerepet kaptak a havonta tartott Lunchroom Symposium-ok, ahol tanárok és diákok olvasták fel verseiket, rap-jeiket stb. A diákok úgy vélték, hogy „az ebédlő a legvibrálóbb hely az iskolában” (174. o.). A diákok maguk is tudatosították, hogy ezt az izgalmat, ezt attitüdöt integrálták az osztálytermi vitákba, ami hozzájárult az intellektuális, emocionális és térbeli távolság csökkentéséhez az informális tér és az osztály között.

A tanterv és a diákok közötti kulturális feszültség oldását szolgálta a multikulturális szemlélet, oktatás is. Szép és izgalmas történeteken, reflexiókon keresztül válik láthatóvá az az interakció, amelyben a diákok ismerkednek saját és mások kultúrájával, történelmével, az amerikai kultúrával, gyakorolhatják az angol (amerikai) nyelvet, amely ösztönözi a pluralizmus (etnikai, nyelvi, nemi stb.) elfogadását, az antirasszista és más diszkrimináció ellenes attitűd kialakulását. Módszerek szempontjából e téren sem az tünik lényegesnek, hogy az órákon különféle pedagógiai „gyógyszereket” (például kooperatív tanulás, portfólió) alkalmaznak, inkább egy sajátos szellemiség és törekvés érvényesülése: Az órákon ne legyen mindig minden elöre megjósolható, a diákok a meglepetések, a kreatív produktumok elkészítésének helyeként lássák az osztályt, a tanítást.

Az érdekessé tételt, a kreativitást szolgálta a tanterv problémásitása a tanulók szükebb és tágabb tapasztalataira építve, a különböző témák (rasszizmus, apartheid politika, fehérkultúra, az erőszak, a szavak hatalma stb.) jelenbe való helyezése, kontextualizálása, a témák dramatizálása, a kérdezéseken keresztül történő tanítás és a viták kiterjesztése a diákok tágabb közösségére is. Az informális tanulási tapasztalatok beépítése egyben egy nem tekintélyelvű osztályt, tanítást is vizionált, amelyben a diákok maguk finomíthatták az arányokat a könyvtudás és a populáris kultúra között, hozzájárulhattak a calypso osztály lényegét adó, izgalmas tanulás- 
hoz. Ebben - ahogy már az előzőekben jeleztem - fontos szerepe volt az autonóm újságnak, de nem csak, mint pedagógiai eszköznek, amely gondoskodik a vitákról, az együttmüködésről, hanem, mint ellenállási eszköznek, amellyel a diákok és a tanárok harcolnak a tanterv természete ellen és küzdenek a kritikai elkötelezettség lehetöségeiért, valamint az osztálytermi társas dinamika demokratikus jellegéért.

Holder túllép azokon a megközelítéseken, amelyek a felnőtteket, a tanárokat a tudás kizárólagos birtokosaként értelmezi, a tanulókat pedig úgy, mint akik elfogadhatják a tanárok által szétosztott tudást. Diákjai felfedezhették, hogy tanáruk nem sztereotípiák, nem külső normák, elvárások alapján közeledik feléjük, hogy kész megismerni, megérteni öket. Kész és képes olyan tanulási környezetet teremteni, amelyben a tanulók a tanitás önirányitó ágenseként jelenhetnek meg, és a támogatott interaktív, reflektív tanulásban érvényesülhet a felszabadító önreflexió ereje. Ezt a mentalitást és gyakorlatot kiegészítette az önmagát háttérbe szorító (önmegsemmisítő) tanítás, amelyben a diákok egyre céltudatosabbakká válnak, egyre inkább képesek az önkorrekció mellett a tanitás befolyásolására is.

Az osztályban kialakuló dialógus, amely az akció és a reflexió kettősségét hordozta, egyben a „világot” átalakitó praxis volt. Egyéni szinten a tanulók saját világukat formálták, konstruálták tudásukat, jelenüket és jövőjüket, de hatottak a szükebb és tágabb közösségükre is. Holder diákjai közül többen részt vettek iskolai szintü szimpóziumokon, előadásokon, sőt tágabb közösséget érintő jelentős, nagy hagyománnyal bíró nevelési konferenciákon, programokon, rádiómüsorokban stb. Több példát kapunk arról, hogy a calypso osztályt képviselve demokratikus dialógust nyitottak diákok, szülők, tanárok, kutatók számára is az iskolázás ügyei kapcsán. A figyelem ellenére a diákok és a tanárok azonban azt érzékelték, hogy marginalizálódtak a nevelési vitákban, de Holderrel egyetértve a legfontosabbnak az tartom, hogy a marginalizáltakat, a némaságra ítélteket bevonták a nevelésröl folyó párbeszédekbe (343. o.).

A könyv mentalitásához illeszkedően folytassuk néhány kérdéssel! Vajon a könyv szemlélete és történet-elmondó stílusa fokozza-e a hagyományos megközelítést valók ellenállását, s ezzel gátolja-e azt a felismerést, hogy szükség van a neveléselmélet és gyakorlat megváltoztatására? Egy pozitivista paradigmát követő gyanakodva kezelheti a müvet: Ha tudományos müről van szó, akkor mit keres benne a sok történet? Ha nem tudományos mü, akkor milyen szerepe lehet a neveléstudomány világában? Egy progresszív nevelés-hívő felvetheti, hogy a mai világban már általánossá vált a tanulóközpontú szemlélet és gyakorlat, így mi újat hozhat ez a könyv. Többen, különösen a volt, ún. szocialista országokban, így nálunk is, feltehetik azt a kérdést, hogy nem túlságosan ideologikus-e a könyv szemléletmódja. E kérdésfeltevés mögött talán az húzódik meg, hogy az említett országokban a kritikai pedagógiai megközelítés szinte ismeretlen volt. A hatalmon lévők a marxizmustól túlságosan elhajlónak látták, a rendszerváltozás után pedig sokan túlságosan marxistának vélték, vélik. Azt mondhatjuk, hogy még napjainkban sincs elegendő 
információ, illetve elmélyült diskurzus erről a megközelítésről. ${ }^{1}$ Lehetne még bővíteni a különféle koncepcionális és módszertani kérdések sorát a könyvvel kapcsolatban, de a folytatás helyett a szerzőnek a következő gondolatára szeretném felhívni a figyelmet: A könyv segíthet újragondolni koncepcióinkat, nézeteinket arról, hogy miért nem és miért tanulnak diákjaink, segíthet áttekinteni, értelmezni, hogy miért nincs kapcsolat a tanulók informális tanulása és az iskolai tanulás között. S ez nem kevés.

A könyvet olvasva megragadja az embert, hogy a szöveg útkeresés, intellektuális barangolás eredménye. Holder, diákjait követve, velük együtt járva, beavatja az olvasót abba a nem egyszerü folyamatba, hogy miként jutottak el a tanulók a csöndtöl a kifejezésig. A fontos kérdésekkel foglalkozó könyv nem csak tanároknak, szülőknek, tanárképzőknek, tanárjelölteknek, diákoknak, oktatáspolitikusoknak, médiumokkal foglalkozóknak, de mindenkinek, akit érdekel a városi ifjúság hangja, aki keresi a válaszokat az iskolai, pedagógiai válságainkra és felelősséggel tekint a jövő felé.

Winthrop R. Holder (2007): Classroom Capypso. Giving Voice to the Voiceless.

Peter Lang Publishing, New York, 164 oldal

\footnotetext{
${ }^{1}$ A kritikai pedagógiáról lásd például: Mészáros György (2005): A „rossz arcúak” szava. A kritikai pedagógia kihívása. Iskolakultúra, 4. sz. 84-101., s e számban Gaskó - Kálmán-Mészáros - Rapos tanulmányát!
} 